\title{
Evaluasi Standar Operasional Prosedur dan Pola Sirkulasi Pengunjung Museum Tjong A Fie: Kajian Historic House Museum
}

\author{
Devy Charisma Sembiring \\ Prodi Arkeologi Fakultas Ilmu Budaya Unud \\ [devycharismasembiring@gmail.com]
}

\begin{abstract}
Museum Tjong A Fie is one of the museum located in Medan City, North Sumatera. This museum was originally a residence of historical figures in the development of the city of Medan is Tjong A Fie originating from China. Museum Tjong A Fie has been designated as a cultural heritage building and used as a museum. This research will discuss Standard Operating Procedures and Visitor Circulation Pattern of Tjong A Fie Museum as a part that must be considered in the organization of the museum. The author uses data collection methods such as observation, interview and literature study and data processing methods through qualitative and comparative analysis. The theory used to refine the interpretation of the results of analysis is Management Theory. Based on the results of research found that the Museum Tjong A Fie has no SOP according to the standard and mandate of PP No. 66 Year 2015. Circulation pattern shows two circulation patterns are unstructured and structured. The recommendations offered include the need to develop SOPs in accordance with the mandate of museum legislation and governance.
\end{abstract}

Key Words: SOP, Circulation Pattern, Historic House Museum

\begin{abstract}
Abstrak
Museum Tjong A Fie merupakan salah satu museum yang terletak di Kota Medan, Sumatera Utara. Museum ini pada awalnya merupakan rumah kediaman tokoh bersejarah dalam perkembangan Kota Medan yaitu Tjong A Fie yang berasal dari Cina. Museum Tjong A Fie telah ditetapkan sebagai bangunan cagar budaya dan dimanfaatkan sebagai museum. Penelitian ini akan membahas Standar Operasional Prosedur dan Pola Sirkulasi Pengunjung Museum Tjong A Fie sebagai bagian yang harus diperhatikan dalam penyelenggaraan museum. Penulis menggunakan metode pengumpulan data seperti observasi, wawancara dan studi kepustakaan serta metode pengolahan data melalui analisis kualitatif dan komparatif. Teori yang digunakan untuk mempertajam interpretasi hasil analisis adalah Teori Manajemen. Berdasarkan hasil penelitian ditemukan bahwa Museum Tjong A Fie belum memiliki SOP yang sesuai standar dan amanat PP Nomor 66 Tahun 2015. Pola sirkulasi menunjukan dua pola sirkulasi yaitu tidak terstruktur dan terstruktur. Rekomendasi yang ditawarkan antara lain adalah perlunya menyusun SOP yang sesuai dengan amanat perundangan dan tata kelola museum.
\end{abstract}

Kata Kunci: SOP, pola sirkulasi, Historic House Museum

\section{Latar Belakang}

Kota Medan merupakan salah satu kota penting di Sumatera yang memiliki akar sejarah sangat panjang. Didalam sejarah perkotaan Indonesia, Medan memang memiliki karakteristik yang berbeda dengan kota-kota bersejarah lainnya di Indonesia. Pada umumnya kota-kota di Indonesia tumbuh dan berkembang akibat dari perluasan politik dan ekonomi pemerintah kolonial Belanda, akan tetapi Medan adalah kota yang tumbuh dan berkembang atas inisiatif, keuletan, kegigihan, dan 
kreativitas pengusaha swasta (Passchier, 1995: 50).

Wajah perkotaan Kota Medan dibangun atas dasar simbolisme rasisme yang kental. Bentuk suatu bangunan memberikan makna tersendiri bagi setiap orang yang melihatnya. Ruang dan bangunan yang ada di Kota Medan mampu menyiratkan siapa dirinya, untuk apa dan untuk siapa dibangun. Medan merupakan kota perkebunan yang sangat melimpah, sehingga bangsa pendatang akan memerlukan tempat tinggal sebagai tempat mereka menghabiskan hariharinya di Medan. Maka dari itu bangsa pendatang akan membangun tempat tinggalnya dengan penggabungan arsitektur bangunan kota asalnya dengan kota yang sedang disinggahi saat itu.

Salah satu etnis yang berperan dalam pembangunan Kota Medan adalah etnis Cina. Etnis ini tinggal secara berkelompok di suatu kawasan (kuarter) Pecinan, yaitu di Kesawan, sisi dari esplanade (Buiskool, 2005 dalam Nurhaiza, 2013: 1). Kesawan saat itu dihuni oleh penduduk etnis Tionghoa, sehingga didominasi oleh rumah dan toko etnis Tionghoa dengan langgam arsitektur neoklasik dan renaissance.

Salah satu bangunan cagar budaya yang mendapat pengaruh etnis Cina di Kota Medan yang dijadikan Historic House Museum adalah rumah Tjong A Fie yang diselesaikan pada tahun 1900. Arsiteknya sendiri ialah Tjong A Fie, seorang Mayor berkebangsaan Cina yang sangat berpengaruh dan berperan penting dalam sejarah Kota Medan. Rumah Tjong A Fie diklaim sebagai salah satu bangunan yang paling besar dan tempat tinggal yang sangat mewah di Indonesia pada saat itu (Laporan Badan Warisan Sumatera). Rumah Tjong A Fie sudah masuk kedalam Benda Cagar Budaya pada tahun 2000 yang dilindungi berdasarkan Peraturan Daerah Kota
Medan No.6 Tahun 1988 yang diperkuat dengan SK Walikota Medan No. $188.342 / 382 / \mathrm{SK} / 1989$ dan No. 188.342/383/SK/2000. Rumah Tjong A Fie menganut perpaduan arsitektur Tionghoa, Eropa, Melayu dan artdeco.

Tjong A Fie adalah seorang pengusaha, bankir, dan kapitan yang berasal dari Tiongkok dan memiliki peran yang penting dalam pembangunan bisnis besar perkebunan di Sumatera, Indonesia.

Tjong A Fie lahir pada tahun 1860 di desa Sung Kow (Mei Hsien), Kanton. Beliau adalah suku asli Hakka Cina. Pada tahun 1875, Tjong A Fie merantau dari negaranya ke Medan untuk menemui saudaranya, Tjong Yong Hian yang sudah merantau selama 5 tahun di Kota Medan. Pada tahun 1875, kehidupan awalnya di Kota Medan ialah menjadi penjaga toko di sebuah toko milik teman kakaknya. Tjong A Fie diangkat menjadi Kapitan pada tahun 1911 dan pindah ke Kota Medan untuk menggantikan posisi Tjong Yong Hian yang telah wafat. Sultan Deli saat itu merekomendasikan Tjong A Fie menjadi anggota gemeenteraad (dewan kota) dan cultuurraad (dewan kebudayaan). Tjong A Fie mengembangkan usaha perkebunan tembakau di Deli, teh di daerah Bandar Baru, serta perkebunan kelapa.

Banyaknya peralihan fungsi dari rumah tempat tinggal menjadi museum adalah fenomena yang sering terjadi di seluruh belahan bumi termasuk di Indonesia.

Pada tahun 1993, S. Butcher Younghans mengusulkan klasifikasi awal rumah-rumah bersejarah dalam tiga kategori besar dalam Unesco 2001: 8 yaitu: (1) Dokumenter, museum rumah bersejarah menceritakan kehidupan seorang tokoh atau budaya di mana lingkungan harus berisi benda asli, dan jika mungkin di tata sesuai dengan letak 
asli, (2) Perwakilan, museum rumah bersejarah mendokumentasikan gaya, suatu zaman atau cara kehidupan pada masa itu, (3) Estetika, museum rumah bersejarah tempat di mana koleksi pribadi yang dipamerkan tidak ada hubungannya dengan rumah itu sendiri, sejarah atau penghuninya harus diperhatikan.

Pendirian Historic House

Museum di Indonesia seharusnya didirikan sesuai dengan Standar Operasional Prosedur (SOP), baik museum milik swasta maupun Pemerintah. Manfaat diberlakukannya SOP pada pendirian sebuah lembaga dan yayasan antara lain: (1) Sebagai standarnisasi cara yang dilakukan aparatur dalam menyelesaikan pekerjaan yang menjadi tugasnya, (2) Mengurangi tingkat kesalahan dan kelalaian yang mungkin dilakukan oleh seseorang aparatur atau pelaksana dalam melaksanakan tugas, (3) Meningkatkan efisiensi dan efektivitas pelaksanaan tugas dann tanggung jawab individual aparatur dan organisasi secara keseluruhan, (4) Menciptakan ukuran standar kinerja yang akan memberikan aparatur cara yang konkrit untuk memperbaiki kinerja serta membantu mengevaluasi usaha yang telah dilakukan, (5) Berorientasi pada pengguna atau pihak yang dilayani. Prosedur-prosedur yang distandarkan harus mempertimbangkan kebutuhan pengguna (costumer's needs) sehingga dapat memberikan kepuasan kepada pengguna.

Dalam penyusunan standar operasional prosedur diperlukan perhatian terhadap pola sirkulasi. Sirkulasi dalam museum atau suatu ruangan museum yang harus beraturan agar suasana museum menjadi lebih baik sesuai tatanannya. Desain suatu ruangan harus memiliki hubungan yang kuat antara pengunjung dengan koleksi yang ada di museum tersebut. Penentuan sirkulasi juga sangat dipengaruhi oleh runtutan cerita pada bangunan yang ingin disampaikan pada pengunjung. Artinya, sirkulasi pengunjung pada museum harus dapat mendukung dalam penyampaian informasi, sehingga dapat membantu pengunjung memahami dan mengekspresiasikan koleksi yang dipamerkan.

Berdasarkan pemaparan di atas, melihat adanya peralihan fungsi dari tempat tinggal menjadi museum, peneliti tertarik untuk meneliti keberadaan Museum Rumah Tjong A Fie. Dalam penjajagan awal peneliti melihat Museum Rumah Tjong A Fie kurang memenuhi standar operasional prosedur dan pola sirkulasi museum yang kurang tertata. Di samping itu, peneliti melihat belum ada yang membahas mengenai transformasi rumah menjadi museum, khususnya museum rumah Tjong A Fie.

\section{Pokok Permasalahan}

Berdasarkan latar belakang yang telah dipaparkan di atas, maka rumusan masalah dari penelitian ini adalah:

1) Bagaimana Standar Operasional Prosedur (SOP) di Museum Tjong A Fie?

2) Bagaimanakah pola sirkulasi pengunjung pada Museum Tjong A Fie?

\section{Tujuan Penelitian}

Tujuan umum dari penelitian ini adalah untuk memberikan kontribusi bagi penelitian selanjutnya, khususnya yang membahas mengenai standar operasional prosedur pada historic house museum. Selain tujuan umum, penelitian ini juga memiliki tujuan khusus untuk menjawab dua permasalahan yang diajukan. Pertama, mengetahui Standar Operasional Prosedur (SOP) Historic House Museum Tjong A Fie. Kedua, mengevaluasi pola sirkulasi pengunjung di Museum TjongA Fie. 


\section{Metode Penelitian}

Penelitian ini merupakan penelitian deskriptif kualitatif dimana keseluruhan data merupakan data berupa uraian-uraian deskripsi. Pengumpulan data dilakukan melalui proses observasi, wawancara, dan studi pustaka. Data dianalisis dengan dua jenis analisis yaitu analisis kualitatif untuk mengolah berbagai data-data uraian yang didapatkan sesuai topik penelitian dan analisis komparatif untuk mengukur SOP Museum Tjong A Fie dengan SOP museum yang lain yang dinilai memiliki SOP yang baik.

\section{Hasil dan Pembahasan}

\subsection{Museum Tjong A Fie sebagai Cagar Budaya dan Historic House Museum}

Museum Tjong A Fie merupakan salah satu bangunan cagar budaya yang sangat penting di Kota Medan. Museum ini dikatakan penting karena memiliki signifikansi nilai penting bagi berbagai ranah. Rumah bersejarah di Indonesia berada di bawah pengawasan dan penguasaan Direktorat Cagar Budaya dan Permuseuman. Asessment atau penilaiannya diatur oleh Undang-Undang Cagar Budaya Nomor 11 tahun 2010. Rumah bersejarah dapat dikategorikan sebagai cagar budaya dalam kategori bangunan. Menurut Undang-Undang Cagar Budaya RI Nomor 11/2010 Bab I Pasal I Ayat 3, sebuah Bangunan Cagar Budaya adalah susunan binaan yang terbuat dari benda alam atau benda buatan manusia untuk memenuhi kebutuhan ruang berdinding dan/atau tidak berdinding, dan beratap.

Lebih lanjut, sebuah bangunan dapat dikategorikan sebagai Bangunan Cagar Budaya apabila memenuhi beberapa kriteria antara (1) berusia 50 tahun atau lebih, (2) mewakili masa gaya paling tidak 50 tahun, (3) memiliki arti khusus bagi sejarah, ilmu pengetahuan, pendidikan, agama, atau kebudayaan, dan (4) memiliki nilai budaya bagi penguatan kepribadian bangsa. Rumah Tjong A Fie jelas memenuhi keempat kriteria tersebut, sehingga ditetapkan sebagai bangunan cagar budaya berdasarkan SK Penetapan dari SK Menteri Nomor 246/M/2015 dan SK Menteri Nomor PM 01/PW. 007/MKP/2010 dengan nomor registrasi nasional RNCB. 20151221.02.000081. Hubungan antara kriteria dan fakta kelayakan cagar budaya Museum Tjong A Fie disajikan pada tabel berikut (Tabel $1)$.

Lebih lanjut, berdasarkan SK Penetapan dari SK Menteri Nomor 246/M/2015 dan SK Menteri Nomor PM 01/PW. 007/MKP/2010, Museum Tjong A Fie didudukan sebagai cagar budaya berperingkat nasional dengan pengelola secara langsung yaitu keluarga Tjong A Fie. Berdasarkan UU Cagar Budaya Nomor 11/2010, sebuah bangunan cagar budaya peringkat nasional adalah cagar budaya yang memenuhi kriteria-kriteria sebagai berikut (a) wujud kesatuan dan persatuan bangsa; (b) karya adiluhung yang mencerminkan kekhasan kebudayaan bangsa Indonesia; (c) Cagar Budaya yang sangat langka jenisnya, unik rancangannya, dan sedikit jumlahnya di Indonesia; (d) bukti evolusi peradaban bangsa serta pertukaran budaya lintas negara dan lintas daerah, baik yang telah punah maupun yang masih hidup di masyarakat; dan/atau (e) contoh penting kawasan permukiman tradisional, lanskap budaya, dan/atau pemanfaatan ruang bersifat khas yang terancam punah. Keseluruhan kriteria tersebut telah dapat dipenuhi oleh Museum Tjong A Fie sehingga kelestarian dari bangunan ini menjadi kewajiban berbagai pihak sesuai UU Cagar Budaya No 11 Tahun 2010. 


\begin{tabular}{|c|c|c|}
\hline No & Kriteria & $\begin{array}{c}\text { Fakta dan Penjelasan Ringkas Kelayakan MTAF } \\
\text { sebagai CB }\end{array}$ \\
\hline 1 & Berusia 50 tahun atau lebih & $\begin{array}{l}\text { Museum Tjong A Fie mulai dibangun pada tahun } \\
1885 \text { dan selesai pada tahun } 1900 \text { sehingga bila dihitung } \\
\text { dari awal pendiriannya telah berusia } 132 \text { tahun hingga } \\
\text { tahun } 2017 \text { atau } 125 \text { tahun saat ditetapkan sebagai BCB } \\
\text { pada } 2010 \text {. }\end{array}$ \\
\hline 2 & $\begin{array}{l}\text { Mewakili masa gaya } \\
\text { paling tidak } 50 \text { tahun }\end{array}$ & $\begin{array}{l}\text { Museum Tjong A Fie memiliki gaya arsitektur dominan Cina } \\
\text { dan dipadukan dengan gaya kolonial (Indis) serta gaya Melayu. } \\
\text { Gaya arsitektur kolonial mewakili gaya akhir abad ke XVII, } \\
\text { begitupula gaya arsitektur Cina dan Melayu yang ditunjukan. }\end{array}$ \\
\hline
\end{tabular}

3 Memiliki arti khusus bagi sejarah, Arti khusus yang ditunjukan oleh Museum Tjong A Fie sesuai ilmu pengetahuan, pendidikan, kriteria UU CB secara ringkas adalah sebagai berikut:

agama, atau kebudayaan

- Sejarah: Museum Tjong A Fie mewakili periode sejarah kolonial di Sumatera Utara secara khusus dan Indonesia pada umumnya. Museum Tjong A Fie merepresentasikan jasa dan peranan Tjong A fie dalam sejarah pembangunan dan pemerintahan kota Medan.

- Ilmu Pengetahuan: Museum Tjong A Fie memiliki nilai tinggi bagi berbagai disiplin ilmu pengetahuan antara lain sejarah, arkeologi, antropologi, arsitektur, dan museologi.

- Pendidikan: Museum Tjong A Fie dapat digunakan sebagai media pendidikan baik keilmuan maupun pendidikan secara umum terutama berkenaan dengan kesadaran sejarah dan pendidikan karakter serta keberagaman.

- Agama: Museum Tjong A Fie secara khusus dimiliki oleh individu dengan keyakinan Konghucu sehingga merupakan representasi seorang Konghucu pada masa lampau.

- Kebudayaan: Museum Tjong A Fie menunjukan ciri budaya etnis Cina di Indonesia. Museum Tjong A Fie merupakan contoh dan bukti eksistensi etnis Cina serta peranan dan upayanya sebagai bagian dari bangsa Indonesia.

\section{Tabel 1. Hubungan antara Kriteria dan Fakta Kelayakan Museum Tjong A Fie sebagai Cagar Budaya}

Selain berstatus sebagai Bangunan Cagar Budaya, Museum Tjong A Fie juga merupakan museum rumah bersejarah (historic house museum). ICOM sebagai organisasi yang menangani museum secara global baru secara serius memberikan batasan terminologis-definitif dari museum rumah bersejarah ini pada 1997, ketika diadakan sebuah konferensi bertajuk Inhibiting History: Historic House Museum yang diselenggarakan di Genoa.
'Museum-homes which are open to the public as such, that is, with their furnishings and collections, even if on successive occasions, which have characteristic colour schemes, and which have never been used to display collections of a different provenance, constitute a museographical category in every particular, and one that varies widely in typological respects. Briefly, the specific character of this type of building is the indissoluble link between container and contained, between palace/house/apartment and permanent 
collections/furnishings/ornamental fixtures (Pavoni, 2001: 17).

Berdasarkan penjelasan yang diberikan Pavoni ini, sebuah museum rumah bersejarah harus memiliki sifat orisinal dan otentik, 'memiliki penghuni", atau dengan kata lain merupakan satu kesatuan dengan sang pemilik-dalam beberapa kasus-living monument, serta koleksi atau barangbarang yang terdapat di dalamnya merupakan barang-barang asli yang telah ada dan dimiliki sang pemilik rumah. Dengan demikian, tipe representative historic house museum dan aesthetics historic house museum ala Butcher dan Younghans tidak memenuhi syarat sebagai sebuah historic house museum.

Dilihat dari fungsinya museum rumah bersejarah memiliki perlindungan, penelitian, dan komunikasi seperti museum-museum lain pada umumnya. Perbedaan yang mendasar antara museum rumah bersejarah dengan museum lain pada umumnya terletak pada metode komunikasinya. Bila museum pada umumnya menggunakan metode komunikasi berbasis 'koleksi-teksmultimedia" maka museum rumah bersejarah mengandalkan metode 'orisinalitas dan keterkaitan historisemosional antara ruang (bangunan), koleksi, dan pemilik'. Dengan metode komunikasi seperti ini, sebuah museum rumah bersejarah memiliki atmosfir yang jauh berbeda dengan museum lain karena menawarkan pengalaman secara langsung berada pada "ruang masa lampau" pada 'masa kini',. Pengunjung akan dibawa secara dekat dan langsung untuk mengapresiasi dan merasakan dirinya berada pada suasana rumah dari periode sejarah dan kondisi sosial tertentu (Cabral, 2001: 41).

Museum Tjong A Fie merupakan salah satu rumah yang tergolong sebagai museum rumah bersejarah karena sebabsebab berikut sebagai berikut:

(1) Museum Tjong A Fie masih mempertahankan bangunan asli berupa rumah dengan perpaduan gaya arsitektur Cina-Indis-Melayu. Museum ini sama sekali tidak mengalami perubahan sejak awal didirikan, kecuali beberapa bagian pernah direstorasi pada tahun 2013 dengan pendanaan dari Ambassador's Fund for Cultural Preservation (AFCP) pada sejumlah titik antara lain adalah bagian atap dan langit-langit.

(2) Museum Tjong A Fie mempertahankan tata ruang rumah dan fungsinya sama seperti semula saat mendiang Tjong A Fie masih hidup kecuali sebuah kamar yang saat ini berubah menjadi ruang galeri foto.

(3) Barang-barang dan furnitur masih asli seperti saat mendiang Tjong A Fie hidup. Berbagai perabotan berupa kursi, ranjang, dan barang lain merupakan barang-barang yang berasal dari awal tahun 1900-an sehingga dapat digolongkan sebagai barang antik dan sudah sangat jarang dapat ditemui pada masa kini.

(4) Museum Tjong A Fie masih dimiliki dan dipakai oleh keluarga/keturunan Tjong A Fie sehingga dapat dikatakan sebagai living monument. Dengan demikian, rumah ini tidak dapat dipisahkan baik secara historis maupun emosional dari penghuninya.

\subsection{Evaluasi Standar Operasional Prosedur dan Pola Sirkulasi Pengunjung Museum Tjong A Fie}

Museum yang baik membutuhkan standar operasi yang ideal agar dapat mewujudkan visi dan misinya. Standar operasi tersebut antara lain adalah prosedur operasional bagi setiap staf yang bertugas. Prosedur operasional berguna untuk membakukan peraturan 
dan prosedur dalam penyelenggaraan museum. Menurut Butcher dan Younghans (1993: 18-20), prosedur operasional pada sebuah historic house museum idealnya dibakukan menjadi sebuah buku manual yang wajib dimiliki oleh petugas museum sebagai acuan tanggung jawab dan standar kerja. Konten dari buku manual prosedur ini berisi:

1) Deskripsi dan Sejarah Museum Bagian ini berisi uraian singkat mengenai sejarah singkat museum, pengetahuan mengenai identitas museum seperti namap dan logo yang digunakan, serta visi dan misi museum. Bagian ini lazimnya juga dilengkapi dengan keterangan mengenai fungsi museum dilihat dari koleksinya serta peranan museum dalam ruang lingkup sosial kemasyarakatan.

2) Prosedur Kerja

Bagian ini berisi pembagian kerja dan organisasi petugas museum, hubungan antar bagian, uraian tugas dan tanggung jawab, serta tata cara pelaksanaan kerja (prosedur). Prosedur kerja dari setiap staf harus disusun secara rinci sesuai standar yang berlaku, atau memenuhi peraturan permuseuman yang diratifikasi oleh institusi terkait. Prosedur kerja ini misalnya berisi mengenai prosedur pengamanan museum, pemeliharaan dan konservasi rutin koleksi, penanganan pengunjung, dan lain sebagainya. Penggunaan sarana dan prasarana museum seperti penggunaan telepon dan kendaraan museum juga masuk dalam bagian ini.

3) Peraturan dan Kebijakan Museum bagi Staf

Bagian ini berisi peraturan dan kebijakan yang dibuat oleh pihak museum berkenaan dengan kewajiban museum terhadap para stafnya, atau dengan kata lain berisi aturan mengenai hak-hak yang diperoleh staf dari pengelola utama museum. Aturan-aturan yang dimaksud berisi mengenai jadwal dan jam kerja, pembayaran gaji, kebijakan lembur dan insentifnya, permohonan cuti dan liburan, asuransi, serta hal-hal lain yang berkaitan dengan hak-hak asasi dari staf.

Dalam konteks permuseuman Indonesia, pentingnya penyusunan Standar Operasional Prosedur diamanatkan oleh Peraturan Pemerintah Republik Indonesia Nomor 66 Tahun 2015 berkenaan dengan Museum. Meskipun tidak tersurat secara langsung dalam segala segi penyelenggaraan museum, kewajiban penyusunan SOP menurut PPRI Nomor 66/2015 ini dapat ditemukan pada Bab IV berkenaan dengan Pengelolaan Koleksi, Bagian Ketiga, Paragraf 3, Pasal 29 ayat (2) yang menyatakan bahwa pengelola museum wajib membuat prosedur operasional standar untuk pemeliharaan koleksi. Selain itu, kewajiban penyusunan SOP juga dapat ditemukan pada $\mathrm{Bab} \mathrm{V}$ berkenaan dengan Pengamanan Museum Pasal 33 ayat (2) yang menyatakan bahwa dalam rangka pengamanan museum, pengelola museum wajib menyusun prosedur operasional standar. PP ini sekali lagi menegaskan kewajiban adanya penyusunan dan pemberlakuan SOP di dalam penyelenggaraan museum terutama yang berkaitan secara langsung dengan pemeliharaan dan pengamanan koleksi museum.

SOP sebuah museum di Indonesia idealnya merujuk pada peraturan perundangan yang berlaku. Peraturan yang memberikan payung hukum pada dunia permuseuman Indonesia adalah Undang-Undang Cagar Budaya Nomor 11 Tahun 2010, serta Peraturan Pemerintah RI Nomor 66 Tahun 2015 tentang Museum. Adapun peraturan yang lain yang lazim dijadikan rujukan untuk 
penyusunan SOP antara lain adalah Keputusan Menteri Pendayagunaan Aparatur Negara Nomor 63/KEP/M.PAN/7/2003, serta Peraturan Menteri Dalam Negeri Nomor 52 Tahun 2011 tentang Standar Operasional Prosedur di Lingkungan Pemerintahan Provinsi dan Kabupaten/Kota. Peraturan lain yang juga perlu dirujuk adalah Peraturan Daerah yang berkaitan dengan kebijakan pengelolaan permuseuman di tingkat provinsi.

Hasil wawancara dengan staf Museum Tjong A Fie menunjukan bahwa pada saat ini sistem kerja mereka belum dilengkapi SOP yang ideal baik dari segi konten maupun rujukan peraturan dan perundangan yang berlaku. Prosedur kerja yang dijalankan oleh staf adalah sistem jobdesk yang menekankan pada tugas dan didasarkan pada instruksi lisan.

Pola sirkulasi yang diamati dalam penelitian ini didasarkan pada beberapa variabel antara lain:

\section{a. Keteraturan Gerak}

Mengikuti pandangan Dean (2002: 53-55), tipe gerak pengunjung museum dapat dibagi dalam dua kategori yaitu tidak terstruktur/acak (unstructured pattern) dan teratur (structured pattern). Pola sirkulasi pengunjung tidak terstruktur menunjukan pergerakan pengunjung secara acak (random) dan berbedabeda pada tiap individu. Pengunjung secara acak bergerak dan memilih pameran yang mereka sukai, berhenti, dan bergerak kembali. Sedangkan pola teratur menunjukan pola yang terstruktur dan cenderung konsisten pada setiap pengunjung.

Pergerakan pengunjung di Museum Tjong A Fie secara umum menunjukan pola tidak terstruktur baik pada pengunjung yang datang mandiri maupun berkelompok. Pola ini dapat diamati pada pengunjung atau kelompok pengunjung yang tidak memanfaatkan jasa pemandu (guide). Pola pergerakan terstruktur ditunjukan oleh pengunjung yang memanfaatkan jasa pemandu (guide) dimana pengunjung bergerak mengikuti arahan dan saran dari pemandu.

\section{b. Kecenderungan Orientatif}

Berdasarkan pengamatan terhadap kecenderungan gerak secara orientatif dijumpai bahwa $70 \%$ pengunjung bergerak dan berbelok ke kanan baik pada awal masuk dari pintu gerbang, maupun selama berada di dalam museum. Pengunjung cenderung memasuki dan berjalan ke arah ruang-ruang di sektor kanan, dan selanjutnya baru bergerak ke arah kiri. Hal ini senada dengan hipotesis gerak pengunjung yang dikemukakan oleh Melton (1972).

\section{c. Vocal Point Room}

Berdasarkan hasil observasi dijumpai fakta bahwa terdapat kecenderungan sirkulasi pengunjung terpusat menuju satu ruang pada setiap lantai. Pada lantai pertama, pengunjung cenderung terpusat dan berdiam lama pada ruang tidur Tjong A Fie, sedangkan pada lantai kedua, pengunjung cenderung terpusat di ruangan ballroom. Kedua ruangan ini sering mengalami penumpukan pengunjung dan menjadi titik perhatian utama.

\section{d. Durasi Kunjungan}

Durasi kunjungan merupakan akumulasi waktu yang dihabiskan oleh pengunjung untuk mengelilingi dan menikmati pameran. Rata-rata pengunjung menghabiskan waktu 1-2 jam untuk menikmati keseluruhan pameran yang disediakan. 


\section{Simpulan}

Berdasarkan uraian yang telah dijelaskan pada Bab sebelumnya, maka pada bagian ini disampaikan beberapa simpulan.

1) Museum Tjong A Fie merupakan bangunan cagar budaya yang memiliki nilai penting tinggi sehingga perlu mendapatkan perhatian dan pelestarian dari berbagai pihak terlebih bila dilihat dari statusnya sebagai Cagar Budaya Nasional. Museum Tjong A Fie sendiri merupakan sebuah rumah kediaman Tjong $\mathrm{A}$ Fie yang dimanfaatkan sebagai museum sehingga dapat diklasifikasikan sebagai museum rumah bersejarah (historic house museum). Berdasarkan hasil penelitian ditemukan bahwa Museum Tjong A Fie belum memiliki Standar Operasional Prosedur yang sebenarnya sangat penting dalam pengelolaan dan penyelenggaraan museum.

2) Pola sirkulasi pada Museum Tjong A Fie didominasi oleh pola pergerakan tidak terstruktur dengan penggunaan orientasi kanan yang signifikan. Adapun dari orientasi gerak, pengunjung cenderung bergerak mengikuti orientasi kanan. Vocal point dari sirkulasi pengunjung terdapat pada ruang tidur Tjong A Fie pada lantai pertama dan ballroom pada lantai kedua.

\section{Daftar Pustaka}

Cabral, Magaly. 2001. 'Exhibiting and Communicating History and Society in Historic House Museums" dalam Museum International Vol 53, Issue 2. Hal. 41-46
Dean, David. 2002. Museum Exhibition:

Theory and Practice. London: Routledge

Nurhaiza. 2015. "Kajian Organisasi Ruang pada Bangunan Rumah Tjong A Fie Berdasarkan Kaidah Arsitektur Cina", Jurnal Arsitekno Vol. 5 No. 5 Hlm 5-9

Pavoni, Rossana. 2001. Towards a Definition and Typology of Historic House Museum dalam Museum International Vol. 53, Hal.16-21.

Passchier, Cor. 1995. Medan, Urban Development by Planters and Entrepreneurs, 1870-1940. Leiden: Research School CNWS

Younghans, Sherry Butcher. 1993. Historic House Museums: A Practical Handbook for Their Care, Preservation, and Management. London: Oxford University Pres 